\title{
Trump and the Populist Authoritarian Parties: The Silent Revolution in Reverse
}

\author{
Ronald Inglehart and Pippa Norris
}

\begin{abstract}
Growing up taking survival for granted makes people more open to new ideas and more tolerant of outgroups. Insecurity has the opposite effect, stimulating an Authoritarian Reflex in which people close ranks behind strong leaders, with strong in-group solidarity, rejection of outsiders, and rigid conformity to group norms. The 35 years of exceptional security experienced by developed democracies after WWII brought pervasive cultural changes, including the rise of Green parties and the spread of democracy. During the past 35 years, economic growth continued, but virtually all of the gains went to those at the top; the less-educated experienced declining existential security, fueling support for Populist Authoritarian phenomena such as Brexit, France's National Front and Trump's takeover of the Republican party. This raises two questions: (1) "What motivates people to support Populist Authoritarian movements?" And (2) "Why is the populist authoritarian vote so much higher now than it was several decades ago in high-income countries?" The two questions have different answers. Support for populist authoritarian parties is motivated by a backlash against cultural change. From the start, younger Postmaterialist birth cohorts supported environmentalist parties, while older, less secure cohorts supported authoritarian xenophobic parties, in an enduring intergenerational value clash. But for the past three decades, strong period effects have been working to increase support for xenophobic parties: economic gains have gone almost entirely to those at the top, while a large share of the population experienced declining real income and job security, along with a large influx of immigrants and refugees. Cultural backlash explains why given individuals support Populist Authoritarian movements. Declining existential security explains why support for these movements is greater now than it was thirty years ago.
\end{abstract}

A permanent link to supplementary materials provided by the authors precedes the references section.

Ronald Inglehart is the Lowenstein Professor of Political Science and a research professor at the Institute for Social Research at the University of Michigan (rf@ umich.edu). He founded the World Values Survey and co-directs the Laboratory for Comparative Social Research at the Higher School of Economics in Moscow.

Pippa Norris is a comparative political scientist who has taught at Harvard for two decades (Pippa_Norris@Harvard. edu). She is Laureate Fellow and Professor of Government and International Relations at the University of Sydney and the McGuire Lecturer in Comparative Politics at the John F. Kennedy School of Government, Harvard University.

environmental protection, gender equality, and tolerance of gays, handicapped people, and foreigners. ${ }^{1}$

Insecurity has the opposite effect. For most of its existence, humanity lived just above the starvation level, and under extreme scarcity, xenophobia becomes realistic: when a tribe's territory produces just enough food to sustain it, and another tribe moves in, it can be a struggle in which one tribe or the other survives. Insecurity encourages an authoritarian xenophobic reaction in which people close ranks behind strong leaders, with strong ingroup solidarity, rejection of outsiders, and rigid conformity to group norms. Conversely, the high levels of existential security that emerged after World War II gave more room for free choice and openness to outsiders.

During the postwar era, the people of developed countries experienced peace, unprecedented prosperity, and the emergence of advanced welfare states, making survival more secure than ever before. Postwar birth cohorts grew up taking survival for granted, bringing an intergenerational shift toward Postmaterialist values. ${ }^{2}$ Survival is such a central goal that when it is threatened, it dominates people's life strategy. Conversely, when it can be taken for granted, it opens the way for new norms concerning everything from economic behavior to sexual orientation and the spread of democratic institutions. Compared with previously prevailing values, which emphasized economic and physical security above all, 
Postmaterialists are less conformist, more open to new ideas, less authoritarian, and more tolerant of outgroups. But these values depend on high levels of economic and physical security. They did not emerge in low-income countries, and were most prevalent among the younger and more secure strata of high-income countries. Security shaped these values in two ways: (1) through an intergenerational shift toward Postmaterialism based on birth cohort effects: younger cohorts that had grown up under secure conditions, gradually replaced older ones who had been shaped by two World Wars and the Great Depression; and (2) through period effects: people respond to current conditions as well as to their formative experiences, with economic downturns making all birth cohorts less Postmaterialist, and rising prosperity having the opposite effect. ${ }^{3}$

The 35 years of rapid economic growth and expanding opportunities that developed democracies experienced following WWII brought pervasive cultural changes contributing to the rise of Green parties and the spread of democracy. But during the most recent 35 years, while these countries still had significant economic growth, virtually all of the gains went to those at the top; the lesseducated experienced declining real income and a sharply declining relative position that fueled support for populist authoritarian parties.

Postmaterialism eventually became its own gravedigger. From the start, the emergence of pervasive cultural changes provoked a reaction among older and less secure strata who felt threatened by the erosion of familiar traditional values. A Materialist reaction against these changes led to the emergence of xenophobic populist authoritarian parties such as France's National Front. This brought declining social class voting, undermining the working-class-oriented Left parties that had implemented redistributive policies for most of the twentieth century. Moreover, the new non-economic issues introduced by Postmaterialists overshadowed the classic Left-Right economic issues, drawing attention away from redistribution to cultural issues, further paving the way for rising inequality. ${ }^{4}$

The Silent Revolution thesis explored the implications of the high prosperity and advanced welfare states that prevailed in high-income countries during the postwar era. We reflect here on the implications of recent backlashes against Postmaterialism. In our conclusion we explore the implications of a new developmental phase these countries are entering that might be called Artificial Intelligence society. This phase offers wonderful opportunities, but has a winner-takes-all economy that encourages rising inequality. Unless counterbalanced by appropriate government policies, this tends to undermine long-term economic growth, democracy, and the cultural openness that was launched in the post-war era.

\section{Cultural Backlash and the Rise of Xenophobic Populist Authoritarian Parties}

The intergenerational shift toward post-materialist values generated support for movements advocating peace, environmental protection, human rights, democratization, and gender equality. These developments first manifested themselves in the politics of affluent societies around 1968, when the postwar generation became old enough to have political impact, launching an era of student protest. ${ }^{5}$ This cultural shift has been transforming post-industrial societies, as younger cohorts replace older ones in the population. The Silent Revolution predicted that as Postmaterialists became more numerous they would bring new issues into politics and declining social class conflict. Postmaterialists are concentrated among the more secure and better-educated strata, but they are relatively favorable to social change. Consequently, though recruited from the more secure strata that traditionally supported conservative parties, they have gravitated toward parties of the Left, supporting political and cultural change.

From the start, this triggered a cultural backlash among older and less-secure people who were disoriented by the erosion of familiar values. Twenty years ago, Inglehart described how this was stimulating support for xenophobic populist parties, presenting a picture that is strikingly similar to what we see today:

The Materialist/Postmaterialist dimension has become the basis of a major new axis of political polarization in Western Europe, leading to the rise of the Green party in West Germany . . . . During the 1980s, environmentalist parties emerged in West Germany, The Netherlands, Belgium, Austria and Switzerland. In the 1990s they made breakthroughs in Sweden and France, and are beginning to show significant levels of support in Great Britain. In every case, support for these parties comes from a disproportionately Postmaterialist constituency. As Figure 1 demonstrates, as we move from the Materialist to the Postmaterialist end of the continuum, the percentage intending to vote for the environmentalist party in their country rises steeply . . . Pure Postmaterialists are five to twelve times as likely to vote for environmentalist parties as are pure Materialists.

West Germany was the scene of the first breakthrough by an environmentalist party in a major industrial nation. In 1983 the Greens were sufficiently strong to surmount Germany's 5 per cent hurdle and enter the West German parliament ... But more recently, the Greens have been pitted against a Republikaner party characterized by cultural conservatism and xenophobia. In the 1994 national elections, the Greens won 7 percent of the vote. The Republikaner, on the other hand, were stigmatized as the heirs of the Nazis and won only two percent of the vote, which was insufficient to win parliamentary representation. Nevertheless, xenophobic forces have already had a substantial impact on German politics, motivating the established parties to shift their policy positions in order to coopt the Republikaner electorate. These efforts included an amendment to the German constitution: to cut down the influx of foreigners, the clause guaranteeing free right of political asylum was eliminated in 


\section{Figure 1 \\ Intent to vote for environmentalist political parties, by Postmaterialist values in four countries having such parties}

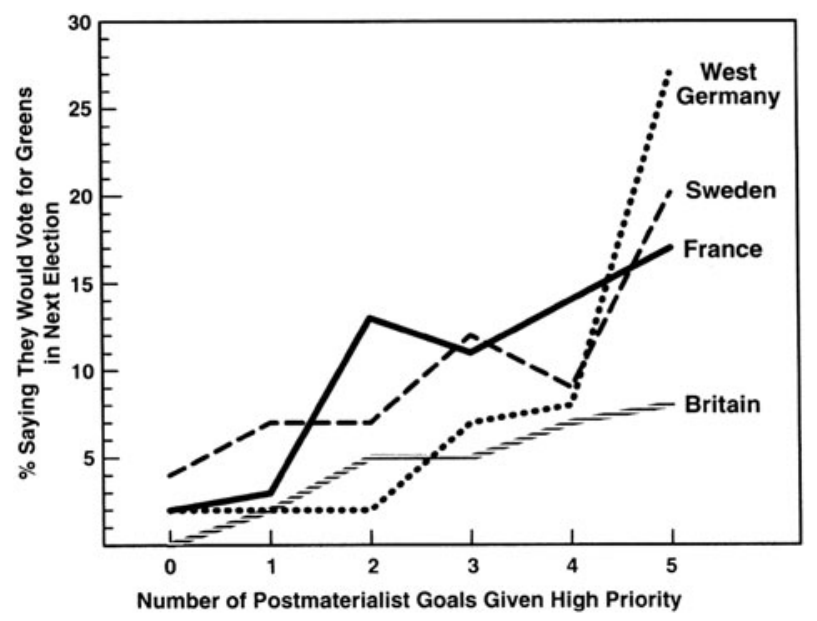

Source: Inglehart 1997, 243.

1993, in a decision supported by a two-thirds majority of the German parliament.

The rise of the Green Party in Germany has also had a major impact, for the Greens are much more than an ecological party. They seek to build a basically different kind of society from the prevailing industrial model... They have actively supported a wide range of Postmodern causes, from unilateral disarmament to women's' emancipation, gay and lesbian rights, rights for the physically handicapped and citizenship rights for nonGerman immigrants. ${ }^{6}$

The Greens and the Republikaner are located at opposite poles of a New Politics dimension, as figure 2 indicates. The Republikaner do not call themselves the Anti-Environment Party; nor do the Greens call themselves the Pro-Immigrant Party. But they adopt opposite policies on relevant issues. The older parties are arrayed on the traditional Left-Right axis established in an era when political cleavages were dominated by social class conflict. On this axis (the horizontal dimension of figure 2) are the Party of Democratic Socialism (the ex-communists) on the extreme Left, followed by the Social Democrats and the Free Democrats, with the Christian Democrats on the Right. Though most people think of the Greens as located on the Left, they represent a new dimension. Traditionally, the Left parties were based on a working-class constituency, and advocated redistribution of income. In striking contrast, the Postmaterialist Left appeals primarily to a middleclass constituency and is only faintly interested in the classic program of the Left. But Postmaterialists are intensely favorable to pervasive cultural changes - which frequently repel the Left's traditional working-class constituency. ${ }^{7}$

The vertical axis on figure 2 reflects the polarization between Postmaterialist and authoritarian populist values.
Figure 2

The social class-based Left-Right dimension and the Postmodern politics dimension in Germany

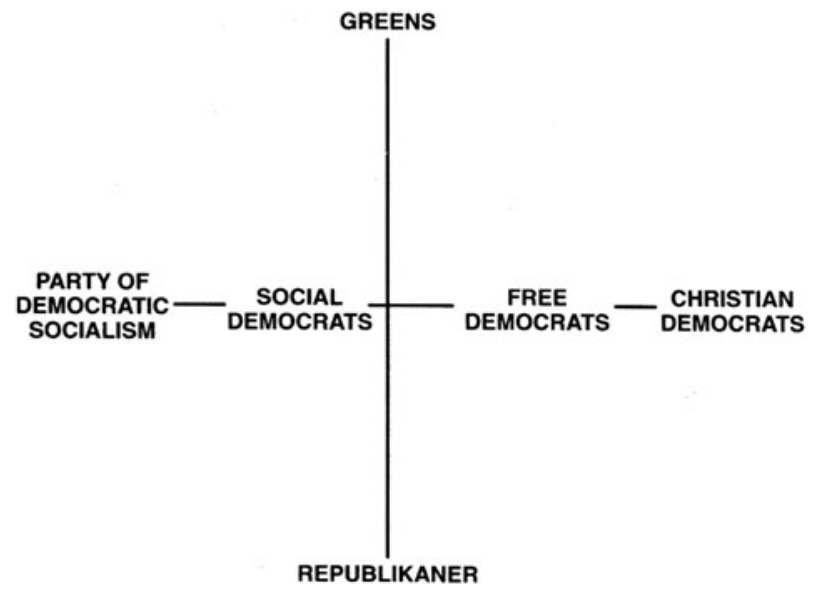

Source: Inglehart 1997, 245.

At one pole, we find openness to ethnic diversity and gender equality; and at the opposite pole we find an emphasis on authoritarian and xenophobic values.

As figure 3 demonstrates, across five advanced industrial societies 70 percent of the pure Materialists supported a policy of reverse affirmative action - holding that "When jobs are scarce, employers should give priority to [one's own nationality] over immigrants." Among the pure Postmaterialist type, only 25 percent are in favor of giving preference to native-born citizens. Similarly, in response to a question about whether they would like to have immigrants or foreign workers as neighbors, Materialists were six times as likely as the Postmaterialists to say they would not want foreigners as neighbors.

A New Politics axis has also emerged in many other countries such as Denmark, Sweden, Switzerland, The Netherlands, France, Austria - and recently, despite its two-party system, the United States, where it stimulated major revolts within each of the two major parties in 2016, with Trump, backed by older, less-secure voters, capturing the Republican presidential nomination and Sanders, backed by younger, well-educated voters, mounting a strong challenge for the Democratic nomination.

\section{Why Is Populist Authoritarianism So Much More Powerful Now Than It Was 30 Years Ago?}

The backlash against Postmaterialism that motivates populist authoritarian parties is not new-it has been present from the start. What is new is the fact that, while these parties were once a fringe phenomenon, today they threaten to take over the governments of major countries. 


\section{Figure 3 \\ Support for giving preference to one's own nationality over immigrants, when jobs are scarce (United States, Britain, France, West Germany, and Sweden)}

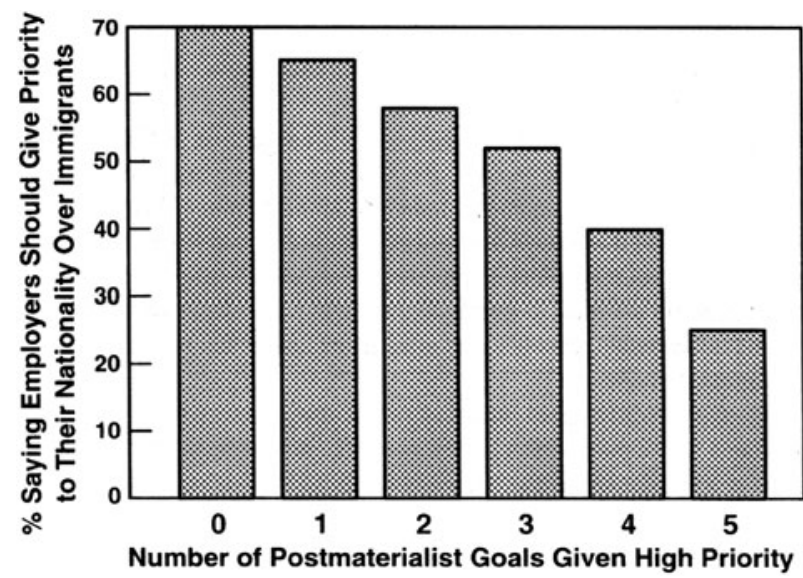

Source: Inglehart 1997, 247.

The rise of populist authoritarian parties raises two key questions: (1) "What motivates people to support xenophobic populist movements?" And (2) "Why is the populist vote so much higher now than it was several decades ago?" Surprising as it may seem, the two questions have different answers.

Support for populist authoritarian parties is motivated by a backlash against the cultural changes linked with the rise of Postmaterialist and Self-expression values, far more than by economic factors. The proximate cause of the populist vote is anxiety that pervasive cultural changes and an influx of foreigners are eroding the cultural norms one knew since childhood. The main common theme of populist authoritarian parties on both sides of the Atlantic is a reaction against immigration and cultural change. ${ }^{8}$ Economic factors such as income and unemployment rates are surprisingly weak predictors of the populist vote.? Thus, exit polls from the U.S. 2016 presidential election, show that those most concerned with economic problems disproportionately voted for Clinton, while those who considered immigration the most crucial problem voted for Trump. ${ }^{10}$

Analysis of European Social Survey data covering 32 countries finds that the strongest populist support comes from small proprietors, not from poorly-paid manual workers. ${ }^{11}$ Only one of five economic variables testedemployment status - was a significant predictor of support for populist authoritarian parties. But when five cultural factors such as anti-immigrant attitudes and authoritarian values were tested, all five of them strongly predicted support for these parties. Authoritarian populist support is concentrated among the older generation, the less-educated, men, the religious, and the ethnic majority - groups that hold traditional cultural values. Older voters are much likelier than younger voters to support these parties, although unemployment rates are higher among the young. And, although women tend to have lower-paying jobs, men are much likelier than women to support populist authoritarian parties.

Today, as 30 years ago, support for xenophobic populist authoritarian parties comes mainly from older, more Materialistic voters. But thirty years ago, the Republikaner and the National Front were relatively small. In September 2016, support for the Alliance for Germany (a successor to the Republikaner) had risen to 16 percent, making it Germany's third-strongest party. ${ }^{12}$ At the same time, surveys indicated that the National Front's leader was leading the field of candidates for the presidency of France. ${ }^{13}$ Other things being equal, one would expect that, as younger, more Postmaterialist birth cohorts replaced older ones in the population, support for these parties would dwindle. But when dealing with intergenerational change, one must take period effects and life-cycle effects into account, as well as birth-cohort effects. Let us examine how this works.

One of the largest cohort analyses ever performed traced the shift from Materialist to Postmaterialist values among the publics of six West European countries, analyzing surveys carried out in almost every year from 1970 to 2008, interviewing several hundred thousand respondents. ${ }^{14}$ Figure 4 shows a simplified model of the results. From the start, younger birth cohorts were substantially more Postmaterialist than older ones, and they remained so. Cohort analysis revealed that after almost forty years, given birth cohorts were still about as Postmaterialist as they were at the start. They had not become more Materialist as they aged: there was no evidence of lifecycle effects. Consequently, intergenerational population replacement brought a massive long-term shift from Materialist to Postmaterialist values. But strong period effects, reflecting current economic conditions, were also evident. From 1970 to 1980, the population as a whole became more Materialist in response to a major recessionbut with subsequent economic recovery the proportion of Postmaterialists recovered. At every time point, the younger cohorts were more Postmaterialist (and more likely to support Green parties) than the older ones (who were more likely to support xenophobic parties). But at any time point, current socioeconomic conditions could make the population as a whole more (or less) Materialist—and more (or less) likely to support xenophobic parties.

We do not have the massive database that would be needed to carry out a cohort analysis of the vote for xenophobic populist parties similar to this analysis of Materialist/Postmaterialist values, so our conclusions can only be tentative, but it is clear that strong forces have been working to increase support for xenophobic parties. 


\section{Figure 4 \\ Model cohort analysis}

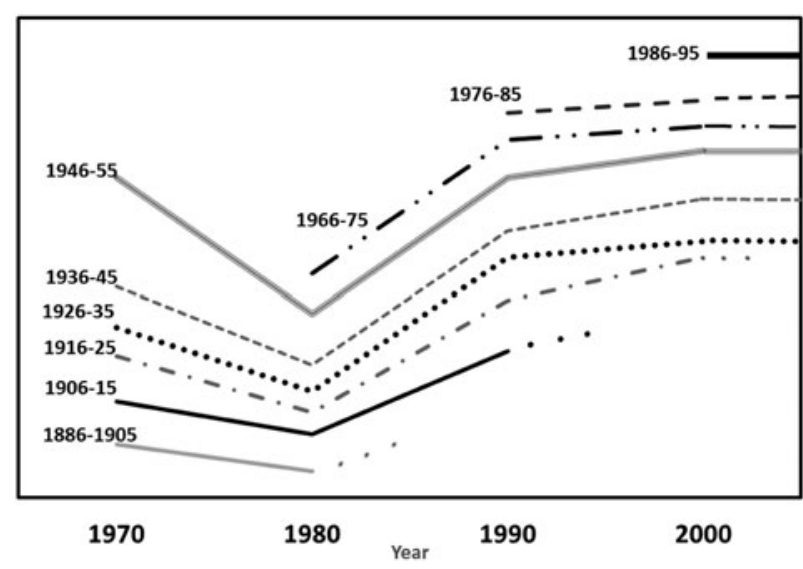

Note: Percentage of Materialists minus percentage of Postmaterialists in six West European countries, 1971-2009.

This seems to reflect the fact that in recent decades, a large share of the population of high-income countries has experienced declining real income, declining job security, and rising income inequality, bringing growing insecurity. In addition, rich countries have experienced a large influx of immigrants and refugees.

Both survey data and historical evidence indicate that xenophobia increases in times of insecurity. ${ }^{15}$ Under the relatively secure conditions of 1928, the German electorate viewed the Nazis as a lunatic fringe party, giving them less than 3 percent of the vote in national elections. But with the onset of the Great Depression, the Nazis won 44 percent of the vote in 1933, becoming the strongest party in the Reichstag. During the Depression several other countries, from Spain to Japan, fell under Fascist governments.

Similarly, in 2005 the Danish public was remarkably tolerant when the publication of cartoons depicting Mohammed led to the burning of Danish consulates and angry demands that Muslim values take precedence over free speech. At the height of the cartoon crisis in 2005-2006, there was no backlash. ${ }^{16}$ But after the Great Recession of 2007-2009, there was. In 2004, before the crisis erupted, the overtly anti-Muslim Danish People's Party won 7 percent of the vote; in 2014, it won 27 percent, becoming Denmark's largest party. In both years, cultural backlash rather than economic deprivation was the strongest predictor of the vote for the Danish People's Party-but rising economic insecurity made people increasingly likely to vote for them. ${ }^{17}$

In high-income countries, younger, Postmaterialist voters are least likely to support xenophobic parties at any given time, but the population as a whole has become increasingly likely to do so. Cultural backlash largely explains why specific people vote for xenophobic parties-but declining economic and physical security helps explain why these parties are much stronger today than they were 30 years ago.

Decades of declining real income and rising inequality have produced a long-term period effect conducive to the populist vote. Thus, although the proximate cause of the populist vote is cultural backlash, its high present level reflects the declining economic security and rising economic inequality that many writers have emphasized.

The fact that birth-cohort effects can coexist with period effects is not intuitively obvious and tends to be overlooked, but it explains the seeming paradox that economic factors do not explain why given individuals vote for populist parties-but do largely explain why the populist vote is much stronger now than in the past.

\section{Its Own Grave-Digger: The Shift from Class-Based Politics to Values Politics}

For most of the twentieth century, working class voters in developed countries generally supported Left-oriented parties, while middle- and upper-class voters supported Right-oriented parties. ${ }^{18}$ Governments of the left tend to bring redistribution and income equality, largely through their influence on the size of the welfare state. ${ }^{19}$ Parties of the class-based Left successfully fought for greater economic equality.

As the century continued, however, postwar generations emerged with a Postmaterialist outlook, bringing declining emphasis on economic redistribution and growing emphasis on non-economic issues. This, plus large immigration flows from low-income countries with different cultures and religions, stimulated a reaction in which much of the working class moved to the right, in defense of traditional values.

The classic economic issues did not disappear. But their relative prominence declined to such an extent that non-economic issues became more prominent than economic ones in Western political parties' campaign platforms. Figure 5 shows how the issues emphasized in thirteen Western democracies evolved from 1950 to 2010. Economic issues were almost always more prominent than non-economic ones from 1950 to about 1983, when noneconomic issues became more prominent. Since then, non-economic issues have dominated the stage.

Moreover, the rise of Postmaterialist issues tended to neutralize class-based political polarization. The social basis of support for the left has increasingly come from the middle class, while a substantial share of the working class shifted to the right. As figure 6 demonstrates, socialclass voting declined markedly from 1950 to 1992 . If 75 per cent of the working class voted for the Left while only 25 per cent of the middle class did so, one would obtain a class-voting index of 50. This is about where the Swedish electorate was located in 1948-but by 1990, Sweden's index had fallen to 26 . By the 1990 s, social-class voting in 
Figure 5

Changing salience of economic vs. noneconomic issues in the party manifestos of thirteen Western Democracies, 1950-2010

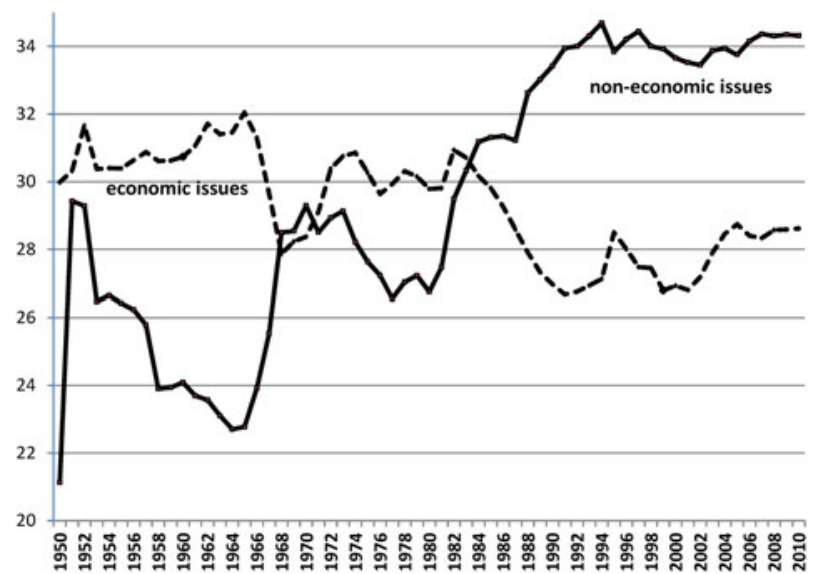

Note: Table-A-1 in the online appendix shows how Zakharov coded issues as Economic or non-Economic.

Source: Party Manifestos data from Austria, Belgium, Canada, Denmark, France, Germany, Ireland, Italy, Netherlands, Norway, Sweden, and Switzerland; Zakharov 2016.

most democracies was less than half as strong as it had been a generation earlier. In the United States, it had fallen almost to zero. Income became a much weaker indicator of the public's political preferences than cultural issues: by wide margins, those who opposed abortion and same-sex marriage supported Republican Presidential candidates over Democrats. The 2016 U.S. presidential elections actually showed a negative social-class voting index, with white working-class voters being more likely to vote for Trump than for Clinton. The electorate had shifted from class-based polarization toward value-based polarization, unraveling a coalition that once brought economic redistribution.

\section{Declining Real Income and Rising Inequality in High-Income Countries}

During the past 40 years, the real income and existential security of the less-educated half of the population of high-income societies has been declining. More recently, artificial intelligence has been undermining the economic position of the more-educated strata, with computers replacing the jobs of the college educated and those with graduate degrees. It once seemed likely that the knowledge society would bring rising living standards for those with advanced skills and higher education but as figure 7 shows, from 1991 to 2014, real incomes in the United States stagnated across the entire educational spectrum.

The highly educated still make substantially higher salaries than the less educated, but since 1991, the real
Figure 6

Trend in social class voting in five Western Democracies, 1947-1992

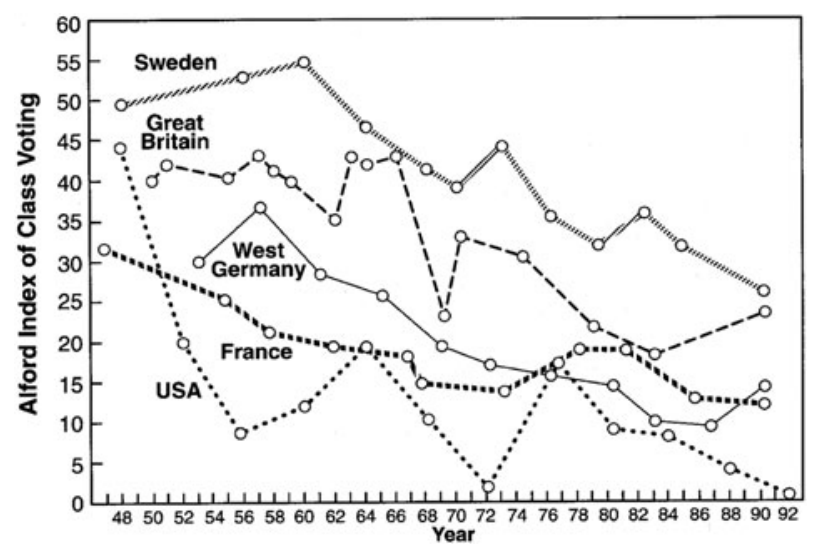

Source: Inglehart 1997, 255.

incomes of not only the less-educated, but even those of college graduates and people with post-graduate educations have stagnated. The problem is not lack of economic growth-U.S. GDP increased substantially. So where did the money go? To the elite of the elite, such as the CEOs of the country's largest corporations. During a period in which the real incomes of highly-educated professionals including doctors, lawyers, professors, engineers, and scientists were flat, the real incomes of CEOs rose sharply. In 1965, CEO pay at the 350 largest U.S. companies was 20 times that of the average worker; in 1989, it was 58 times as high; and in 2012 CEOs earned 354 times as much as the average worker. ${ }^{20}$ This vastly increased disparity doesn't reflect improved CEO performance: economic growth was higher in the 1960s than it is today.

Economic inequality declined in advanced industrial societies for most of the twentieth century, but since about 1970 it has been rising steeply, as Piketty has demonstrated. ${ }^{21}$ In 1915, the richest 1 percent of Americans earned about 18 percent of the national income. From the 1930s to the 1970s, their share fell below 10 percent - but by 2007 , it had risen to 24 percent. The U.S. case is far from unique: all but one of the OECD countries for which data are available experienced rising income inequality (before taxes and transfers) from 1980 to $2009 .^{22}$

Economic inequality is ultimately a political question, as the Swedish case demonstrates. Though it had considerably higher levels of inequality than the U.S. in the early twentieth century, by the 1920s Sweden had attained lower levels and has retained them to the present. In the United States, the top decile got almost half of the total income in 2010, while in Sweden it got only 28 percent. The advanced welfare-state culture 


\section{Figure 7 Median salary of employed people by educa- tional level in United States, 1991-2013}

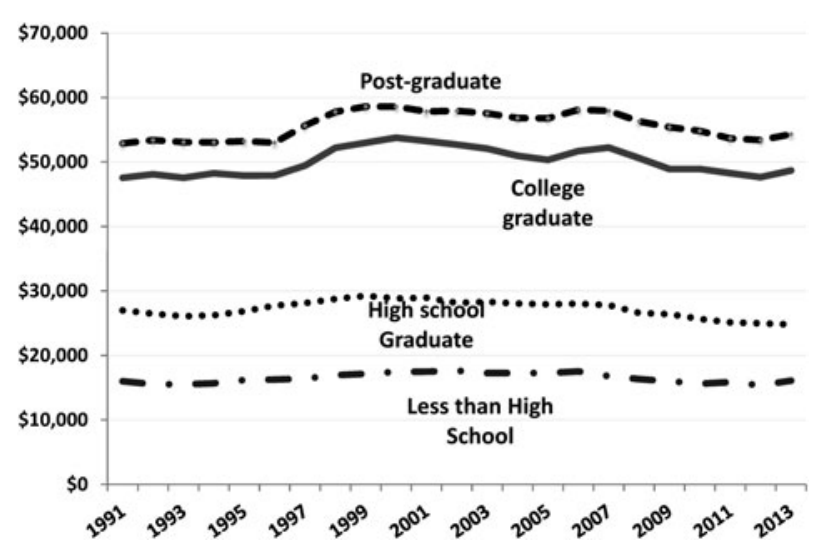

Note: 2013 U.S. dollars.

Source: United States Census Bureau 2014.

introduced by Sweden's long-dominant Social Democrats had lasting effects. Conversely, neo-conservative regimes led by Ronald Reagan and Margaret Thatcher in the 1980s weakened labor unions and sharply cut back state regulation. They left a heritage in which conservatives seek to reduce government expenditures with almost religious zeal — and the United States and United Kingdom now show significantly higher levels of income inequality than other developed capitalist societies. The dramatic change that occurred when former communist countries abandoned their state-run economies is further evidence that income inequality reflects a country's political system: the collapse of communism brought even larger increases in income inequality than those in the West. ${ }^{23}$

Piketty holds that rising inequality is the normal state of affairs, which was temporarily offset by exogenous shocks (the two World Wars and the Great Depression). But historical evidence doesn't support this claim. Inequality began falling in many capitalist countries before World War I, and major welfare state legislation was adopted well after World War II. Moreover, Sweden established one of the world's most advanced welfare states without participating in either World War.

Economic equality or inequality ultimately depends on the balance of political power between owners and workers, which varies at different stages of economic development. The transition from agrarian society to industrial society created a demand for large numbers of industrial workers. Though initially exploited, when they became organized in labor unions and working-classoriented political parties, they were able to elect governments that redistributed income, regulated finance and industry and established extensive welfare states that brought growing income equality throughout most of the twentieth century. Since about 1970, organized labor has dwindled to a small minority of the work force, weakening its political influence. Government redistribution and regulation of the economy were cut back during the Reagan-Thatcher era; and the rise of the knowledge society tends to establish a winner-takes-all economy in which the rewards go mainly to those at the very top.

As Milanovic demonstrates, the world as a whole is getting richer, but it is doing so on a very uneven trajectory that he describes as an "elephant curve." 24 Most of the world's population made large gains in real income from 1988 to 2008. The largest gains were made by the 40 percent living in China, India, Thailand, Vietnam, and Indonesia, where real incomes increased by 80 percent. In sharp contrast, the decile living in the high-income societies of Western Europe, the United States, Canada, and Australia started from a much higher base, but made no gains. But the greatest absolute gains by far were made by the very rich in high-income countries, who started out with very high incomes and made massive gains, sharply increasing inequality.

The contrasting performance of China-India-Indonesia-Thailand-Vietnam versus that of the high-income countries reflects the fact that the two groups of countries are at different phases of modernization. Most of the people in the former group are making the transition from agricultural society to industrial society, in which the average person's bargaining power is inherently greater than in service economies. The people in high-income countries have made the transition from industrial society to service economies, where jobs are highly differentiated according to educational levels, giving the less-educated little or no bargaining power. This tendency becomes increasingly strong as these societies move into artificial intelligence society, where almost everyone's job can be automated, leaving them at the mercy of those at the top.

\section{Pay No Attention to That Man Behind the Curtain}

Conservatives argue that rising inequality really doesn't matter. As long as the economy as a whole is growing, everyone will get richer, and we should pay no attention to rising inequality.

But everyone isn't getting richer. For decades, the real income of the developed world's working class has been stagnant and the material basis of what counts as an acceptable standard of living has been rising. In the nineteenth century, having enough to eat counted as doing well and "a chicken in every pot" was an inspiring political slogan. Subsequently, automobiles were a luxury, and the slogan "a car in every garage" was an ambitious goal. Today, automobiles and television sets are part of a minimal standard of living in high-income countries, but the working class has increasingly precarious job prospects and an awareness of the vast economic gains made by those 
above them-and feel that they are shut out from the benefits of growth. In 2000, 33 percent of the U.S. public described themselves as "working class;" by 2015, that figure had risen to 48 percent. $^{25}$

Conservative economists used to argue that even very steep taxes on the top earners wouldn't raise enough money to change things substantially. That is no longer true. Inequality has risen so rapidly that by 2007 , the top one percent took home 24 percent of the U.S. total income $\mathrm{e}^{26}$ and in 2011 the top one percent of households controlled 40 percent of the nation's wealth. ${ }^{27}$ In 2014 , Wall Street paid out in bonuses roughly twice as much as the total earnings of all Americans who work full time at the federal minimum wage. ${ }^{28}$ And in 2015,25 hedge fund managers were paid more than all the kindergarten teachers in the United States. ${ }^{29}$

For centuries, it seemed to be a law of nature that modernization brought rising life expectancy. But since 2000 the life expectancy of middle-aged non-Hispanic whites in the U.S. has been falling. ${ }^{30}$ The decline is concentrated among those with less than a college education, and is largely attributable to drug abuse, alcohol abuse, and suicide. This is a sign of severe malaise; the only comparable phenomenon in modern times was the sharp decline in male life expectancy linked with the collapse of the Soviet Union. In service-sector economies, economic growth no longer raises everyone's standard of living.

\section{Political Mobilization Shapes the Rise and Fall of Inequality}

Inequality reflects the balance of political power between elites and mass, which is shaped by modernization. Early industrialization brought ruthless exploitation of workers, low wages, long working days, and suppression of unions. But eventually, industrialization narrowed the gap between elites and masses by redressing the balance of political skills. Urbanization brought people into closer proximity; workers were concentrated in factories facilitating communication among them, and the spread of mass literacy put them in touch with national politics, enabling workers to organize for effective action. In the late nineteenth century and early twentieth century, unions won the right to organize, enabling workers to bargain collectively. The expansion of the franchise gave workers the vote, and left-oriented political parties mobilized them. These newly mobilized voters eventually elected governments that implemented redistributive policies such as progressive taxation, social insurance, and extensive welfare states, causing inequality to decline for most of the twentieth century.

High-income societies are now entering the stage of Artificial Intelligence Society. This brings substantial economic gains but inherently tends to produce a winnertakes-all economy in which the gains go almost entirely to the top. Artificial Intelligence makes it possible for com- puters to replace even highly-educated professionals. Left solely to market forces, secure well-paid jobs will continue to disappear even for the highly educated. In Artificial Intelligence Society, the key economic conflict is no longer between a working class and a middle class, but between the top one percent and the remaining 99 percent.

Currently, the rich are able to shape policies that increase the concentration of wealth. Martin Gilens presents evidence that the U.S. government responds so faithfully to the preferences of the most affluent ten percent of the country's citizens that "under most circumstances, the preferences of the vast majority of Americans appear to have essentially no impact on which policies the government does or doesn't adopt."31

The safety net that once protected the American public is unraveling, as politicians and corporations cut back on health care, income security and retirement pensions. ${ }^{32}$ In the United States, financial institutions employ about 2.5 lobbyists for every representative in Congress, largely to dissuade them from regulating banks more closely. ${ }^{33}$ The fact that Congress has been so hesitant to regulate banks, even after inadequate regulation of the financial sector led to a Great Recession that cost millions of people their jobs and homes, suggests that this investment is paying off.

Joseph Stiglitz argues convincingly that a tiny minority of extremely rich individuals has attained tremendous political influence in the United States, which they are using to shape policies that systematically increase the concentration of wealth, undermining economic growth, and diminishing investment in education, research, and infrastructure. ${ }^{34}$ Hacker and Pierson argue that winnertake-all politics in the United States is based on an alliance between big business and conservative politicians that has cut taxes for the rich from 75 percent in 1970 to less than 35 percent in 2004 and has sharply reduced regulation of the economy and financial markets. ${ }^{35}$ This is indeed the proximate cause. But the ability of U.S. politicians to adopt one-sidedly pro-business policies was enhanced by the weakening of organized labor, globalization, and the trend toward a winner-takes-all economy. Fifty years ago, capitalists and conservative politicians were probably just as greedy and as clever as they are today-but they were restrained by an alliance of strong labor unions and left-oriented political parties that was able to offset the power of the rich, and establish redistributive policies. Modernization has eroded this political alignment, and inequality is rising in virtually all highly-developed countries.

\section{Growth without Good Jobs}

In 1860, the majority of the U.S. workforce was employed in agriculture. By 2014, jobs in the agricultural sector had virtually disappeared but this didn't bring widespread unemployment and poverty because of 
a massive rise in industrial employment. But by 2010, automation and outsourcing had reduced the ranks of industrial workers to 10 percent of the workforce. The loss of industrial jobs was offset by a dramatic rise in servicesector jobs, which now employs most of the U.S. work force (refer to figure 8).

The service sector includes a high-technology sector, consisting of everyone employed in the information, finance and insurance, and professional, scientific, and technical-services categories. It is often assumed that the high-tech sector will produce large numbers of high paying jobs. But - surprising as it may seem-employment in this area is not increasing. As Figure 8 shows, the high-tech sector's share of total employment in the United States has been constant since statistics became available about three decades ago. As figure A-2 in the online appendix indicates, this is also true of Canada, Germany, France, Sweden, and the United Kingdom. Unlike the transition from agricultural to industrial society, the rise of the knowledge society is not generating large numbers of secure well-paid jobs.

Initially, only unskilled workers lost their jobs to automation, but today even highly-skilled occupations are being automated. Artificial intelligence is replacing lawyers who used to do legal research, resulting in growing unemployment and a 30 percent drop in law school enrollment from 2010 to 2015. Expert systems are being developed that can do medical diagnoses more accurately and faster than physicians. The print journalism profession has been virtually annihilated and tenuretrack jobs in higher education are disappearing, making it a much less attractive career. And increasingly, computer

\section{Figure 8}

\section{Percentage of U.S. workforce employed in agriculture and industry (1860-2012), in ser- vice sector (1900-2012), and high-technology sector since 1986}

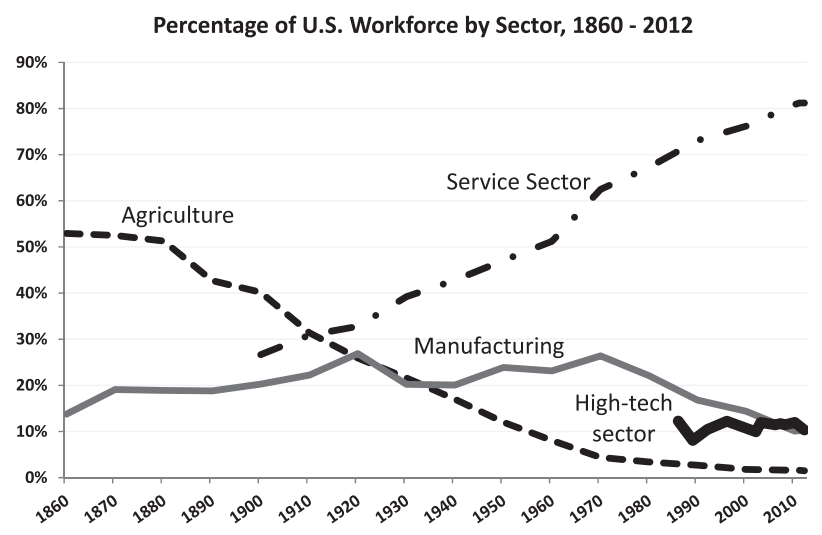

Note: Data not available for service sector before 1900 and for hightechnology sector before 1986 .

Sources: National Science Board 2014, United States Bureau of Labor Statistics 2014,United States Bureau of the Census 1977. programs themselves are being written by computerswhich is one reason why the number of jobs in the hightechnology sector is not growing.

Even highly-educated workers are no longer moving ahead, with gains from the large increases in gross domestic product going almost entirely to a thin stratum of financiers, entrepreneurs, and managers at the very top. As artificial intelligence replaces people, unregulated market forces tend to produce a situation in which a tiny minority controls the economy, while the majority have precarious jobs, serving them as gardeners, waiters, nannies, and hairdressers - a future foreshadowed by the social structure of Silicon Valley today.

The Knowledge Society inherently has a winner-takesall economy. In manufacturing material objects, industrial societies have niches for a wide range of products-from small cars that cost very little to produce, to mid-size cars, to large cars, to extremely expensive luxury cars. Lower quality products were competitive on price. But in the Knowledge Economy, the cost of reproduction is close to zero: once you have produced Microsoft software, it costs almost nothing to produce and distribute additional copies-which means that there is no reason to buy anything but the top product. In this winner-takes-all economy, Bill Gates became a billionaire before he was 40, and Mark Zuckerberg became a billionaire before he was 30 . The rewards to those at the top are immense- but increasingly, they are limited to those at the very top.

In 2012, the gap between the richest one percent and the remaining 99 percent in the United States was the widest it has been since the 1920 s. $^{36}$ In the long run, growing economic inequality is likely to bring a resurgence of mass support for government intervention-but for now, this is held in check by emotionally-hot cultural issues such as immigration and same-sex marriage, that enable conservative politicians to draw the support of lowincome voters.

Political stability and economic health require a return to the redistributive policies that were in place for most of the twentieth century. A punitive attitude toward the top one percent would be counter-productive-it includes some of the country's most valuable people. But moving toward a more progressive income tax is perfectly reasonable. In 1950-1970, the U.S. top 1 percent paid a much higher share of their income in taxes than they do today. This did not strangle economic growth-we had higher growth-rates than we have now. Two of the richest Americans, Warren Buffet and Bill Gates, advocate higher taxes for the very rich They also argue that the inheritance tax is a relatively painless way to raise funding that is badly needed for increased investment in education, medical care, research and development, and infrastructure. But powerful conservative interests have moved the United States in the opposite direction, sharply reducing the inheritance tax. 
The groundswell of support for populists ultimately reflects economic insecurity, but its immediate cause is a backlash against rapid cultural changes. Trump promised to make America great again-meaning that he would make America go back to being like it used to be. This is one reason why older voters are much likelier than younger voters to support populist parties. But Trump's policies of deregulating the financial sector and reducing taxes on the very rich are the opposite of what is needed by the people left behind; these policies will make America great for billionaires who pay no income tax.

Hochschild argues that the paradox of low-income Americans voting against their own economic interests by supporting conservative Republicans reflects a powerful emotional reaction. ${ }^{37}$ It is not just that right-wing politicians are duping them by directing their anger to cultural issues, away from possible solutions to their status as a permanent underclass. Less-educated white Americans feel that they have become "strangers in their own land." They see themselves as victims of affirmative action and betrayed by "line-cutters"-African-Americans, immigrants, refugees, and women-who jump ahead of them in the queue for the American Dream. They resent liberal intellectuals who tell them to feel sorry for the line-cutters, and dismiss them as bigots when they don't. Unlike most politicians, Donald Trump provides emotional support when he openly expresses racist and xenophobic feelings.

We may be witnessing a shift in political cleavages comparable to that of the 1930s, which saw the rise of Fascism, on one hand, and the emergence of the New Deal and its West European parallels on the other hand. The reaction against rapid cultural change and immigration has brought a surge of support for xenophobic populist parties among the less-secure strata. But rising inequality has also produced an insurgency on the Left by politicians like Bernie Sanders and intellectuals like Joseph Stiglitz and Thomas Piketty who stress the need for redistributive policies. Thus far this movement has been supported mainly by younger and more-educated voters. Cultural politics continues to dominate electoral behavior-but demands for political realignment are emerging.

Increasingly, high-income societies have winner-takes-all economies that tend to establish societies dominated by a small minority, while the overwhelming majority have precarious jobs. If left to market forces, this tendency is likely to prevail. But government offers a countervailing force that can reallocate resources to benefit society as a whole. In recent decades government has done the opposite, but for much of the twentieth-century, working-class-oriented parties elected governments that brought declining inequality. Though this class-based coalition has disintegrated, a huge majority of the population now has an incentive to elect governments committed to reallocation. If a large share of the 99 percent becomes aware of this, it can create a new winning coalition. There are signs that this is happening.
In surveys carried out from 1989 to 2014, respondents around the world were asked whether their views came closer to the statement "Incomes should be made more equal" or that "Income differences should be larger to provide incentives for individual effort." In the earliest polls, majorities in four-fifths of the 65 countries surveyed believed that greater incentives for individual effort were needed. But over the next 25-years, publics in 80 percent of the countries surveyed, including the United States, became more favorable to reducing inequality. ${ }^{38}$

So far, emotionally-charged cultural issues cutting across economic lines have hindered the emergence of a new coalition. But both the rise of populist movements and the growing concern for inequality reflect widespread dissatisfaction with existing political alignments. In the long run, a coalition based on the 99 percent is likely to emerge.

Artificial Intelligence Society is making greater resources available, but government intervention will be required to reallocate a significant portion of these resources into creating meaningful jobs in infrastructure, environmental protection, health care, education (from pre-school to post-graduate levels), research and development, care of the elderly, and the arts and humanities-in order to improve the quality of life for society as a whole, rather than blindly maximizing GDP. Developing effective programs to attain this goal will be a crucial task for social scientists and policy-makers during the next 20 years.

\section{Notes}

1 Inglehart 1971, 1977, 1990.

2 Subsequent research demonstrated that Postmaterialist values are part of a still-broader shift from survival values to self-expression values. For simplicity, "Postmaterialist" as used here refers to this broader cultural shift.

3 Inglehart 1971, 1977; Inglehart and Welzel, 2005.

4 Inglehart 1990, 1997.

5 Inglehart 1990, 1997; Inglehart and Welzel 2005; Norris and Inglehart 2011.

6 Inglehart 1997, 243-245.

7 Norris 2005.

8 Ivarsflaten 2008.

9 Sides and Citrin 2007.

10 Election 2016.

11 Inglehart and Norris 2016.

$12 \mathrm{http} / / / \mathrm{www} . \mathrm{dw} . c 0 \mathrm{~m} / \mathrm{en} / \mathrm{new}$-poll-shows-alternativefor-germany-gaining-support/a-19569448

13 https://www.theguardian.com/news/datablog/ 2014/sep/08/le-pen-tops-presidential-poll-for-firsttime-ever

14 For a detailed discussion of this cohort analysis, see Inglehart and Welzel 2005, 99-107. 
15 Inglehart, Moaddel, and Tessler 2006; Billiet, Meuleman, and De Witte 2014.

16 Sniderman et al. 2014.

17 Inglehart 2015.

18 Lipset 1960.

19 Bradley et al. 2003; Iversen and Sostice 2009.

20 Sabadish and Mishel 2013.

21 Piketty 2014.

22 World Bank 2015.

23 Whyte 2014.

24 Milanovic 2016.

25 http://www.gallup.com/poll/182918/feweramericans-identify-middle-class-recent-years.aspx

26 Saez and Zucman 2014.

27 Stiglitz 2011.

28 Wolfers 2015.

29 http://www.politifact.com/truth-o-meter/statements/ 2015/jun/15/hillary-clinton/hillary-clinton-tophedge-fund-managers-make-more- $/$.

30 Case and Deaton 2015.

31 Gilens 2012.

32 Hacker 2008.

33 Stiglitz 2013.

34 Ibid.

35 Hacker and Pierson 2010.

36 Wiseman 2013.

37 Hochschild 2016.

38 Inglehart 2016.

\section{Supplementary Material}

- Appendix Figure A-1.

https://doi.org/10.1017/S1537592717000111.

\section{References}

Billiet, Jaak, Bart Meuleman and Hans De Witte. 2014. "The Relationship between Ethnic Threat and economic insecurity in times of economic crisis." Migration Studies 2(2): 135-161.

Bradley, David, Evelyne Huber, Stephanie Moller, François Nielsen, and John D. Stephens. 2003. "Distribution and Redistribution in Postindustrial Democracies." World Politics 55(2): 193-228.

Case, Anne and Angus Deaton. 2015. "Rising Morbidity and Mortality in Midlife among White Non-Hispanic Americans in the 21st Century." Proceedings of the National Academy of Sciences 112(49): 15078-83.

Election 2016: New York Times Exit Poll, November 8, 2016.

Gilens, Martin 2012. Affluence and Influence. Princeton, NJ: Princeton University Press.

Hacker, Jacob. 2008. The Great Risk Shift. New York: Oxford University Press.

Hacker, Jacob and Paul Pierson. 2010. Winner-Take-All Politics. New York: Simon and Schuster.
Hochschild, Arlie Russell. 2016. Strangers in Their Own Land. New York: The New Press.

Inglehart, Ronald 1971. "The Silent Revolution in Europe," American Political Science Review 65(4): 991-1017. 1977. The Silent Revolution. Princeton, NJ:

Princeton University Press. . 1990. Cultural Shift in Advanced Industrial Society. Princeton, NJ: Princeton University Press. . 1997. Modernization and Postmodernization.

Princeton, NJ: Princeton University Press.

- 2015. "Insecurity and Xenophobia: Comment on Paradoxes of Liberal Democracy." Perspectives on Politics 13(2): 468-70. 2016. "Inequality and Modernization: Why Equality Is likely to Make a Comeback." Foreign Affairs 95(1): 2-10.

Inglehart, Ronald, Mansoor Moaddel, and Mark Tessler. 2006. 'Xenophobia and In-Group Solidarity in Iraq: A Natural Experiment on the Impact of Insecurity' Perspectives on Politics 4(3): 495-505.

Inglehart, Ronald and Pippa Norris. 2016. "Trump, Brexit, and the rise of Populism." Paper presented at 2016 meeting of the American Political Science Assocation.

Inglehart, Ronald and Christian Welzel. 2005. Modernization, Cultural Change and Democracy. New York: Cambridge University Press.

Ivarsflaten, Elisabeth. 2008. "What Unites Right-Wing Populists in Western Europe?" Comparative Political Studies 41: 3-23.

Iversen, Torben and David Soskice. 2009. "Distribution and Redistribution." World Politics 61(3): 438-86.

Lipset, Seymour Martin. 1960. Political Man. New York: Anchor Books.

Milanovic, Branko. 2016. Global inequality. Cambridge: Harvard University Press.

Norris, Pippa 2005. Radical Right. New York: Cambridge University Press.

Norris, Pippa and Ronald Inglehart. 2011. Sacred and Secular. New York: Cambridge University Press.

Piketty, Thomas. 2014. Capital in the Twenty-First Century. Cambridge: Harvard University Press.

Sabadish, Natalie and Lawrence Mishel. 2013. "CEO Pay in 2012 Was Extraordinarily High Relative to Typical Workers." Issue Brief\#367. Washington, DC: Economic Policy Institute.

Saez, Emmanuel and Gabriel Zucman. 2014. "Wealth Inequality in the U.S. since 1913." NBER Working Paper. Available at http://gabriel-zucman.eu/uswealth/.

Sides, John and Jack Citrin, 2007. "European Opinion about Immigration:" British Journal of Political Science 37: 477-504.

Sniderman, P. M., M. B. Petersen, R. Slothuus, and R. Stubager. 2014. Paradoxes of Liberal Democracy. Princeton, NJ: Princeton University Press. 
Stiglitz, Joseph 2011. "Of the 1 Percent, by the 1 Percent, for the 1 Percent." Vanity Fair, May. 2013. The Price of Inequality. New York: Norton.

Whyte, Martin. 2014. "Soaring Income Gaps: China in Comparative Perspective." Daedalus 143(2): 39-52.
Wiseman, Paul. 2013. "Richest one percent earn biggest share since '20s." AP News, September 10.

Wolfers, Justin. 2015. "All You Need to Know about Income Inequality, in One Comparison." New York Times, March 13.

World Bank. 2015. GINI Index. Available at http://data. worldbank.org/indicator/SI.POV.GINI/. 